\title{
The Evaluation of Urine Samples by Gram Staining and Matrix Assisted Laser Desorption/lonization Time-of-Flight Mass Spectrometry (MALDI-TOF MS) in Rapid Diagnosis of Urinary Tract Infections
}

\author{
Ummuhan Su Topalca $^{1 \oplus}$, Nurcan Saygili $^{1 \oplus}$, Nur Anliacik $^{1 \oplus}$, Mehmet Emin Bulut $^{1 \oplus}$, Elif Aktas ${ }^{1 \oplus}$
}

ABSTRACT:

The evaluation of urine samples by Gram staining and matrix assisted laser desorption/ ionization time-of-flight mass spectrometry (MALDI-TOF MS) in rapid diagnosis of urinary tract infections

Objective: The aim of this study was the evaluation of the efficacy of examination of urine samples by Gram staining and MALDI-TOF MS system.

Materials and Methods: A total of 251 out of 555 urine samples sent for culture to Sisli Hamidiye Etfal Training and Research Hospital Clinical Microbiology Laboratory between September 14 to September 18, 2015 were randomly selected and included in the study. Detection of pure bacterial growth of $\geq 105 \mathrm{CFU} / \mathrm{ml}$ was aimed by using Gram staining and MALDI-TOF MS. Urine samples yielding at least one bacterium in at least five microscopical fields by Gram staining were tested by MALDI-TOF MS (Bruker Daltonics, Germany). Urine culture was performed by using "Chromagar Orientation" medium (BD, USA). Culture, Gram staining and MALDI-TOF MS results were compared.

Results: In $28(11.1 \%)$ of the 251 samples tested, bacterial growth of $\geq 105 \mathrm{CFU} / \mathrm{ml}$ was observed. While single bacterial agent was isolated in 27 of 28 samples, one sample yielded two different bacterial species. In 25 of 28 samples, bacteria with a single morphology was observed with Gram staining. MALDI-TOF MS could identify the bacterial agents in 18 of these 25 samples. While bacterial growth of $\geq 105 \mathrm{CFU} / \mathrm{ml}$ wasn't observed in six samples yielding bacteria with a single morphology by Gram staining, contamination was observed in three samples. When MALDI-TOF MS results were investigated for these nine samples, it was observed that MALDI-TOF MS gave a result of "Escherichia coli" in one of the contaminated samples and no result was obtained in the remaining eight samples. When the culture is considered as the gold standard, three false-negative and nine false-positive results were observed by Gram staining while 10 false-negative and one false-positive results were observed by MALDI-TOF MS. The sensitivity, specificity, and positive and negative predictive values were $89.2 \%, 95.9 \%, 73.5 \%$, and $98.6 \%$, respectively, for Gram staining, and $64.2 \%$, $99.5 \%, 94.7 \%$, and $95.6 \%$, respectively, for MALDI-TOF MS.

Conclusions: Combined use of Gram staining and MALDI-TOF MS in the direct testing of urine samples has allowed bacterial identification for more than half of the samples yielding bacterial growth of $\geq 105 \mathrm{CFU} / \mathrm{ml}$ in culture, within two hours after receipt of the samples in the laboratory, with high specificity, and positive and negative predictive values. The use of MALDI-TOF MS with higher sensitivity rates will be useful in the diagnosis of urinary tract infections. Keywords: Gram staining, MALDI-TOF MS, urine

ÖZET:

İdrar yolu enfeksiyonlarının hızlı tanısında idrar örneğinin gram boyama ve matriks aracılı lazer desorpsiyon iyonizasyon - uçuş zamanlı - kütle spektrometrisi (Maldi - Tof Ms) ile incelenmesinin etkinliği

Amaç: Bu çalışmada, idrar yolu enfeksiyonlarının hızlı tanısı için idrar örneğinin Gram boyama ve MALDi-TOF-MS sistemiyle incelenmesinin etkinliğinin değerlendirilmesi amaçlanmışıı.

Gereç ve Yöntem: Şișli Hamidiye Etfal Eğitim ve Araştırma Hastanesi Laboratuvarına 14 Eylül-18 Eylül 2015 tarihleri arasında kültür için gönderilen 555 idrar örneğinin 251'i rastgele seçilerek çalışmaya alındı. Gram boyama ve MALDi-TOFMS'le $\geq 105 \mathrm{CFU} / \mathrm{ml}$ saf bakteri üremesinin tespiti hedeflendi. En az beş alanda, en az bir bakteri görülen idrarlar MALDiTOF-MS'le (Bruker Daltonics, Almanya) ile test edildi. Kültür, "Chromagar Orientation” besiyerinde (BD, ABD) yapıldı. Bulqular: Çalısıllan 251 örneğin 28'inde (\%11.1) $\geq 105 \mathrm{CFU} / \mathrm{ml}$ üreme oldu. 28 örneğin 27 'sinde tek etken izole edilirken, bir örnekte iki etken mevcuttu. 28 örneğin 25'inde Gram boyamayla tek morfolojide bakteri görüldü. MALDI-TOFMS'le bu 25 örneğin 18'inde bakteri tanımlanabildi. Gram boyamayla tek morfolojide bakteri görülen altı örnekte 2105CFU/mI üreme olmazken, üç örnekte kontaminasyon mevcuttu; bu dokuz örneğin MALDI-TOF-MS sonuçları değerlendirildiğinde, MALDI-TOF-MS kontamine örneklerin birinde "Escherichia coli" sonucunu verdiği, bunun dışındaki sekiz örnekte sonuç alınmadığı görüldü. Kültür altın standart alındığında; Gram boyamayla üç yalancı-negatif, dokuz yalancı-pozitiflik, MALDI-TOF-MS'le 10 yalancı-negatif, bir yalancı-pozitiflik gözlendi. Gram boyama için duyarllık \%89.2, özgüllük \%95.9, pozitif kestirim değeri \%73.5, negatif kestirimdeğeri \%98.6 iken, MALDI-TOF-MS için duyarlılık \%64.2, özgüllük \%99.5 pozitifkestirim değeri \%94.7, negatif kestirim değeri \%95.6 olarak belirlendi. Sonuç: Direkt idrar örneğinde Gram boyama ve MALDI-TOF-MS'in birlikte kullanımıyla kültürde $\geq 105 \mathrm{CFU} / \mathrm{ml}$ üreme olan örneklerin yarısından fazlasında örneğin, laboratuvara ulaşmasından sonraki iki saat içerisinde yüksek özgüllük ve yüksek pozitif ve negatif kestirim değerleriyle etken bakteri tanımlaması yapmak mümkün olmuştur. MALDI-TOF MS'indaha yüksek duyarlııkla kullanılabilir olması idrar yolu enfeksiyonlarının tanısında faydalı olacaktır.

Anahtar kelimeler: Gram boyama, MALDI-TOF-MS, idrar

'Sisli Hamidiye Etfal Training and Research Hospital, Microbiology Laboratory, Istanbul - Turkey

Address reprint requests to / Yazışma Adresi: Ummuhan Su Topalca,

Sisli Hamidiye Etfal Training and Research Hospital, Microbiology Laboratory,

Istanbul - Turkey

E-mail / E-posta:

ust.10980@gmail.com

Date of receipt / Geliş tarihi:

February 7, 2017 / 7 Şubat 2017

Date of acceptance / Kabul tarihi: July 21, 2017 / 21 Temmuz 2017 


\section{INTRODUCTION}

Urinary tract infections (UTIs); count the majority of infections both in patients under outpatient followup and in inpatients. UTI is an important infectious disease in the group of patients with underlying disease/with immunosuppression and in the immunocompetent population, from infancy to the elderly (1). The prevalence of UTIs varies geographically, and the major risk factors include advanced age, prior history of UTI, and diabetes mellitus (2). It has been reported that $4.1-7.5 \%$ of severe bacterial infections in children with fever are associated with urinary tract infections. However, the majority of patients with UTIs are women, with a lifetime experience rate of about $50 \%$ this infection. While the UTI rate is $5 \%$ in young women and $0.1 \%$ in young men, this rate is over $20 \%$ in women and $10 \%$ in men over 65 years. While there is an increased risk of invasive or systemic infection in certain groups of patients, such as men, children, and pregnants, disease complications are more frequent in elderly patients, in immunosuppressive patients, and in patients with neurological disorders or underlying diseases.

UTI most commonly occurs when bacteria in the patient's own intestinal flora reach the urinary tract from the urethra by ascending way. The most common etiologic factor in children and adolescent populations is, Escherichia coli, which is present predominantly in the faeces and has specific virulence factors such as the ability to adhere to the uroepithelial cells. Klebsiella pneumoniae, Enterococcus faecalis, Staphylococcus saprophyticus are other important pathogens that play a role in urinary tract infections (1-3).

Considering that UTIs are associated with significant morbidity, mortality and cost, it is crucial for the laboratory to obtain rapid and significant results, early recognition of these infections and early initiation of appropriate treatment and avoidance of unnecessary antibiotic use (1-5).

Culture is the gold standard in the diagnosis of urinary tract infections. However, reporting of culture results lasts two to three days. Gram staining is useful when the number of bacteria in the specimen is high, while it gives an idea of bacterial morphology, it is not sufficient for identification (6). Matrix-assisted Laser Desorption Ionization-Flight Time-Mass Spectrometry (MALDI-TOF MS), which is a fast automated identification system that has been used in clinical microbiology laboratories in recent years, is based on the unique proteomic fingerprint peak patterns of microorganisms themselves. With MALDITOF MS, results can be obtained in minutes using a single colony of the microorganism growing in the culture in MS. There are limited studies on the use of MALDI-TOF-MS in direct clinical specimens. Sensitivity rates range from $50 \%$ to $90 \%$ in these studies (7-16).

The aim of this study was to evaluate the efficacy of examination of urine samples by Gram staining and MALDI-TOF MS system.

\section{MATERIAL AND METHOD}

Randomly selected 251 of the 555 urine samples sent for culture between September 14 and September 18, 2015 were studied at the laboratories of Sisli Hamidiye Etfal Training and Research Hospital. $\geq 105$ $\mathrm{CFU} / \mathrm{mL}$ of pure bacterial growth with Gram staining and MALDI-TOF-MS was targeted.

Samples were evaluated by Gram staining without centrifugation. Leukocytes were rated as $+:<1 /$ LPF , 2+: 1-9/LPF, 3+:10-25/LPF and 4+:>25/ LPF at $100 \mathrm{X}$ magnification (LPF). Bacteria were examined at 1000X magnification (OIF) (17). The presence of leukocyte and bacteria were noted. Urine with single morphology bacteria in Gram staining were tested with MALDI-TOF-MS (Bruker Daltonics, Germany). The urine with bacteria with more than single morphology were not evaluated with MALDI-TOF-MS.

The analysis with MALDI-TOF-MS was based on the method described by Kim et al. (7); the sample amount was modified to $1.5 \mathrm{ml}$ instead of $3 \mathrm{ml}$. According to this method, $1.5 \mathrm{~mL}$ of urine sample for testing with MALDI-TOF-MS was taken in eppendorfs and centrifuged at $2000 \mathrm{~g}$ for 30 seconds to remove leukocytes. The resulting supernatant was centrifuged at $14000 \mathrm{~g}$ for 10 minutes and the pellet formed after this centrifugation was washed with deionized water. 
$1.5 \mathrm{ml}$ of $0.1 \%$ sodium dodecyl sulfate (SDS) was added to the pellet and incubated at $37^{\circ} \mathrm{C}$ for 10 minutes. After centrifugation and washing at $14000 \mathrm{~g}$ for 10 minutes, the formed pellet was spread to the areas over the "target" of the MALDI-TOF-MS device and left to dry. 1 microliter matrix was added and tested with MALDI-TOF-MS after drying. Analysis was performed with MALDI Biotyper 3.1 software (Bruker Daltonics, Germany).

Culture was performed simultaneously on "Chromagar Orientation" medium (Becton Dickinson, USA). The urine samples were quantitatively plated, and the plates were incubated overnight at $37^{\circ} \mathrm{C}$. Conventional methods for identification procedures, BD Phoenix ${ }^{\mathrm{TM}}$ (Becton Dickinson, USA) automatization system and MALDI-TOF-MS system, were used.

\section{RESULTS}

Of the 251 cases studied, 98 were children and 153 were adult patients. $14.7 \%$ of the patients were women between $15-45$ years of age. $92.4 \%$ of the samples belonged to outpatient clinics and $7.6 \%$ belonged to hospitalized patients. In 251 cases, 28 (11.1\%) had $\geq 105 \mathrm{CFU} / \mathrm{ml}$ of growth. Of the remaining 223 samples, 134 showed no growth, 48 had few bacterial or genitourinary system flora elements, and
41 had contamination. Of the 28 samples, single agent was isolated from 27 , while one sample contained two agents (20 E. coli, 3 K. pneumoniae, 1 Citrobacter koseri, 1 Proteus mirabilis, 1 E. coliStreptococcus gallolyticus, 1 Streptococcus agalactiae, $1 \mathrm{E}$. faecalis). Only bacteria with single morphology was seen in 25 of 28 samples with Gram staining (Table-1).

Bacteria could be identified in 18 of these 25 samples with MALDI-TOF-MS. There was no growth of $\geq 105 \mathrm{CFU} / \mathrm{ml}$ in six samples with bacteria with single morphology with Gram staining, while three samples were contaminated; when the results of MALDI-TOF-MS in these nine samples were examined, it was observed that MALDI-TOF-MS showed "E. coli" as the result in one of the contaminated samples and no results were obtained in the other eight samples. When culture is taken as gold standard; Three false-negativity, nine falsepositivity with Gram staining, 10 false-negativity, and one false-positivity with MALDI-TOF-MS were observed (Table-1). Six of the 10 isolates unidentifies with MALDI-TOF-MS were E. coli, two were $K$. pneumoniae, and two were E. faecalis.

When the culture is taken as gold standard, the sensitivity, specificity, positive and negative predictive values obtained for Gram staining and MALDI-TOF-MS are shown in Table-2.

Table-1: Culture, Gram staining and MALDI-TOF MS results for the samples included in the study

\begin{tabular}{llccc}
\hline & & & Culture* & \\
\cline { 3 - 5 } & & Positive & Negative & Total \\
\hline Gram staining** & Positive & 25 & 9 & 34 \\
& Negative & 3 & 214 & 217 \\
& Total & 28 & 223 & 251 \\
MALDI-TOF MS & Positive & 18 & 1 & 23 \\
& Negative & 10 & 222 & 232 \\
& Total & 28 & 223 & 251 \\
\hline
\end{tabular}

${ }^{*}$ Culture positivity for this study was accepted as $\geq 100,000 \mathrm{CFU} / \mathrm{ml}$ pure growth. ${ }^{* *}$ At least one bacterium with single morphology seen in at least five fields in Gram staining were evaluated as positive.

Table-2: According to the culture; sensitivity, specificity, positive and negative predictive values of Gram staining and MALDI-TOF MS

\begin{tabular}{lcccc}
\hline & Sensitivity & Specificity & PPV & NPV \\
\hline Gram staining & $89.2 \%$ & $95.9 \%$ & $73.5 \%$ & $98.6 \%$ \\
MALDI-TOF MS & $64.2 \%$ & $99.5 \%$ & $94.7 \%$ & $95.6 \%$ \\
\hline
\end{tabular}

PPV; pozitive predictive value, NPV, negative predictive value 


\section{DISCUSSION}

Urinary tract infections are the most common infections in medical practice. Considering that urinary tract infection is the leading cause in sepsis etiology, the importance of rapid diagnosis of infection emerges. Although E. coli is the most frequent pathogenic microorganism, the importance of rational antimicrobial use due to the increase in antimicrobial resistance rates today, short-term identification of the causative microorganism and the treatment planning based on the possible susceptibility profiles is critical (18).

Gram stain preserves its value for rapid diagnosis when the number of bacteria in the sample is high. The appearance of one organism in each immersion area is compatible with growth of $105 \mathrm{CFU} / \mathrm{ml}$. Gram staining is not enough for identification, even though it gives an idea of bacterial morphology. MALDITOF-MS, which has been started to be used in clinical microbiology laboratories in recent years, is able to identify microorganisms in a short period of time from microorganism colonies produced in culture, and studies regarding their use in direct clinical specimens such as blood and urine specimens are improving (7-16,19). In our study, Gram staining and MALDI-TOF MS were used together to identify urine samples first with potential for bacterial growth by Gram staining, then for identification of bacteria in urine with single bacteria, MALDI-TOF MS was used.

In the study of Ferreira et al. (9), which they performed identification by MALDI-TOF MS through direct urine sample is one of the first in the literature. Identification from a direct clinical sample is carried out with pellets obtained after several successive centrifugation steps and the methods in the literature show differences such as centrifugation time/cycle, short-term incubations, use of SDS or Tween-80 which have detergent-effect during the formation of this pellet $(7-16,19)$. Sánchez-Juanes et al. (13) treated the urine sample with SDS before centrifugation and aimed to minimize the false results by releasing the microorganisms by lysis of the cells such as the epithelium, leucocyte, etc.. Identification of bacteria has been possible when $55.9 \%$ of $E$. coli isolates, $37.6 \%$ of $E$. faecalis isolates, $50 \%$ of $K$. pneumoniae, Staphylococcus aureus and Pseudomonas aeruginosa isolates, which could not be identified by MALDI-TOF MS has been processed with SDS, then retested gain. Burillo et al. (10) used Tween-80, another material with detergent-effect, and reported a sensitivity of $79.2 \%$. Kim et al. (7) incubated the pellet with SDS following various centrifugation steps. Sensitivities in this study were reported as $98.6 \%$ for gram-negative enteric agents, $60 \%$ for nonfermenter gram-negative bacilli, $44.4 \%$ for gram-positive cocci, and $20 \%$ for yeast. In our study, the method described by Kim et al. (7), ie the amount of urine sample, was changed to 1.5 $\mathrm{ml}$ instead of $3 \mathrm{ml}$ due to the suitability to the centrifuge used in our laboratory. However, the sensitivity rates obtained after our study were observed to be lower than the rates indicated in the reference used (64.2\%). The sensitivity rates to be lower than expected, were thought to be due to the reduced amount of sample used. An advanced study is planned with a higher number of urine samples, in which the amount of sample, the agent with detergent-effect and the effect of extraction operations before the process can be assessed and optimized in the MALDI-TOF MS system.

In our study, it was possible to identify more than half of the samples with $\geq 105 \mathrm{CFU} / \mathrm{ml}$ growth in culture by using Gram staining and MALDI-TOF MS in direct urine samples together, with high specificity and high positive and negative predictive values within for example, two hours after reaching the laboratory. The fact that MALDI-TOF MS can be used with higher sensitivity will create a new perspective on the diagnosis of urinary tract infections.

\section{REFERENCES}

1. McCarter YS, Burd EM, Hall GS, Zervos M. 2009. Cumitech 2C, Laboratory Diagnosis of Urinary Tract Infections. Coordinating ed., S.E. Sharp. ASM Press. Washington, DC.

2. Tandogdu Z, Wagenlehner FM. Global epidemiology of urinary tract infections. Curr Opin Infect Dis 2016; 29: 73-9. [CrossRef]

3. Sobel JD, Kaye D. Urinary Tract Infections. In Mandell GL, Douglas and Bennett's Principles and Practice of Infectious Diseases, $7^{\text {th }}$ Edition. 2009; 957-85.

4. Burd EM, Kehl KS. A Critical appraisal of the role of the clinical microbiology laboratory in the diagnosis of urinary tract infections. J Clin Microbiol 2011; 49: 34-8. [CrossRef] 
5. Nicolle LE, Bradley S, Colgan R, Rice JC, Schaeffer A, Hooton TM. Infectious Diseases Society of America; American Society of Nephrology; American Geriatric Society. Infectious Diseases Society of America guidelines for the diagnosis and treatment of asymptomatic bacteriuria in adults. Clin Infect Dis 2005; 40: 643-54. [CrossRef]

6. Urine Cultures. In Clinical Microbiology Procedures Handbook, Garcia, LS. (ed.) $3^{\text {rd }}$ ed. ASM Press. Washington DC. 2007.

7. Kim Y, Park KG, Lee $K$, Park YJ. Direct identification of urinary tract pathogens from urine samples using the Vitek MS system based on matrix-assisted laser desorption ionization-time of flight mass spectrometry. Ann Lab Med 2015; 35: 416-22. [CrossRef]

8. Wang $X-H$, Zhang $G$, Fan $Y Y$, Yang $X$, Sui WJ, Lu XX. Direct identification of bacteria causing urinary tract infections by combining matrix-assisted laser desorption ionization-time of flight mass spectrometry with UF-1000i urine flow cytometry. J Microbiol Methods 2013; 92: 231-5. [CrossRef]

9. Ferreira L, Sánchez-Juanes F, Mu-oz-Bellido JL, GonzálezBuitrago JM. Rapid method for direct identification of bacteria in urine and blood culture samples by matrix-assisted laser desorption ionization time-of-flight mass spectrometry: intactcell vs. extraction method. Clin Microbiol Infect 2011; 17: 1007-12. [CrossRef]

10. Burillo $A$, Rodríguez-Sánchez $B$, Ramiro $A$, Cercenado $E$, Rodríguez-Créixems M, Bouza E. Gram-stain plus MALDI-TOF MS (matrix-assisted laser desorption ionization-time of flight mass spectrometry) for a rapid diagnosis of urinary tract infection. PloSone 2014; 9: e86915. [CrossRef]

11. Köhling HL, Bittner A, Müller KD, Buer J, Becker M, Rübben $H$, et al. Direct identification of bacteria in urine samples by matrixassisted laser desorption/ionization time-of-flight mass spectrometry and relevance of defensins as interfering factors. J Med Microbiol 2012; 61: 339-44. [CrossRef]
12. March Rosselló GA, Gutiérrez Rodríguez MP, de Lejarazu Leonardo RO, et al. Procedure for microbial identification based on Matrix-Assisted Laser Desorption/Ionization-Time of Flight Mass Spectrometry from screening- positive urine samples. Apmis 2014; 122: 790-5. [CrossRef]

13. Sánchez-Juanes F, Siller Ruiz M, Moreno Obregón F, Criado González M, Hernández Egido $S$, et al. Pretreatment of urine samples with SDS improves direct identification of urinary tract pathogens with Matrix-Assisted Laser Desorption IonizationTime of Flight Mass Spectrometry. J Clin Microbiol 2014; 52: 335-8. [CrossRef]

14. Wieser A, Schneider L, Jung J, Schubert S. MALDI-TOF MS in microbiological diagnostics-identification of microorganisms and beyond (mini review). Appl Microbiol Biotechnol. 2012; 93: 965-74. [CrossRef]

15. Tai-Fen Lee, Hao Lee, Chung-Ming Chen, Shin-Hei Du, Ya-Chih Cheng et al. Comparison of the accuracy of Matrix-Assisted Laser Desorption Ionization-Time Of Flight Mass Spectrometry with that of other commercial identification systems for identifying Staphylococcus saprophyticus in urine. Journal of clinical microbiology 2013; 51: 1563-66. [CrossRef]

16. Segawa S, Sawai S, Murata S, Nishimura M, Beppu M. et al. Direct application of MALDI-TOF mass spectrometry to cerebrospinal fluid for rapid pathogen identification in a patient with bacterial meningitis. Clin Chim Acta 2014; 435: 59-61. [CrossRef]

17. Gram staining. In Clinical Microbiology Procedures Handbook, Garcia, LS. (ed.) $3^{\text {rd }}$ ed. ASM Press. Washington DC. 2007.

18. Willke Topçu A, Söyletir G, Doğanay M. Enfeksiyon Hastalıkları ve Mikrobiyolojisi. Idrar Yolu Enfeksiyonları. 3. baskı. İstanbul. Nobel Tıp Kitabevleri. 2008: 1487-99.

19. Romero-Gómez M-P, Gómez-Gilc R, Pa-o-Pardo JR, Mingorance J. Identification and susceptibility testing of microorganism by direct inoculation from positive blood culture bottles by combining MALDI-TOF and Vitek-2 Compact is rapid and effective. J Infect 2012; 65: 513-20. [CrossRef] 